\title{
Evolution of Bhumija Shikhara and Distribution of Bhumija Shrines in India
}

\author{
Maulik Hajarnis \& Bhagyajit Raval \\ Faculty of Architecture, Parul University, Waghodia, Vadodara, Gujarat, India \\ Email: hajarnismaulik@gmail.com
}

Received August 26, 2016; Revised October 15, 2016; Accepted October 17, 2016; Published October 22, 2016

\begin{abstract}
The present paper begins with a brief on the meaning and essence of a Hindu temple. It talks about the types of classification of the Hindu temples in India, on the basis of its physical attributes. The authors then try to trace the evolution of the Bhumija shikhara chronologically. The paper examines the Bhumija mode with respect to its meaning and references in literature. Finally the paper mentions various Bhumija shrines in various states of the country chronologically. The description ends with maps showing spatial distribution of Bhumija shrines across India and a graph showing state wise Bhumija shrines with respect to their time-line.
\end{abstract}

Keywords: Temple, Bhumija, Shikhara, Shrine, India

\section{Introduction}

As the title of the paper suggests, this paper talks about the evolution of the Bhumija spire and the spatial locations of various Bhumija shrines in India. But before we arrive at the description of Bhumija spire and its peculiar features, it is essential to have a brief understanding of the meaning of the Hindu Temple. The Hindu temple is based on a simple and direct concept of worship with a ritual of prayer involving a dialogue between the devotee and the deity of the temple (Hardy, 1995). The sole purpose of every Hindu temple is to be a house for a god whose image or idol is installed at the heart or core of the monument. This concept applies to any scale or form of a Hindu Temple ranging from a road-side shrine to any of the grandest work of royal patronage.

\section{Classification of Hindu temples}

Hindu temples can be classified on the basis of several aspects. For instance, they could be classified on the basis of any of the following criteria:

1. The Deity of the Temple: If the temple is devoted to Shiva it is a Shivalaya or a Shaiva temple. If it is devoted to Parshvanatha, it becomes a Jain derasara and so on.

2. The Number of Shrines in the Temple: If the temple has one shrine it is a single shrine temple. If it has two shrines besides a common Mandapa (prayer hall) it is a double shrine temple. If it has three shrines attached to a common mandapa, it is a Triple shrine temple.

(c) AesthetixMS 2016. This Open Access article is published under a Creative Commons Attribution Non-Commercial 4.0 International License (http://creativecommons.org/licenses/by-nc/4.o/), which permits non-commercial re-use, distribution, and reproduction in any medium, provided the original work is properly cited. For citation use the DOI. For commercial re-use, please contact editor@chitrolekha.com. 
3. The Plan - form of the Sanctum: If the sanctum has been planned on an orthogonal grid it is an orthogonal plan. If the plan of the sanctum of a temple is generated on the principle of a rotated square, it is a stellate plan.

4. The Circumbulation Path: If the temple possesses an ambulatory path it is a 'Sandhara' temple. If it is devoid of a circumbulatory path it is a 'Niradhara' temple.

5. The Number of Projections or Buttresses in the exterior face of the sanctum: If there are 3 nos. of projections or buttresses (one central and two on each side/corner offsets) then it is a 'triratha' temple. If there are 5 buttresses or offsets it is a 'pancharatha' temple. Similarly 'saptaratha', 'navaratha' and so on. However it has to be noted that the number of projections is always an odd number since the plan of any temple is symmetrical about the central axis.

6. The Regional modes of Temple Architecture in India: If the temple is situated in the northern part of India, it is a 'Nagara' temple. A temple in South India is termed as a 'Dravida' or 'Karnata' temple. And likewise all temples located in the central part of India are termed as 'Vesara' temples. (Albanese, 2004)

Similarly there are several other ways of classifying temples on the basis of anga, number of storeys or bhumi in elevation of the Bhumija Shikhara and so on. But since the current paper has to focus on the evolution of the Bhumija Shikhara we have to understand further bifurcation of the regional classification of temples mentioned in the previous paragraph.

\begin{tabular}{|c|l|}
\hline Language & \multicolumn{1}{|c|}{ Modes } \\
\hline 1. Nagara & Latina \\
\hline & Sekhari \\
\hline & Bhumija: orthogonal \\
\hline & Bhumija: stellate \\
\hline & Valabhi \\
\hline 2. Dravida & Orthogonal \\
\hline & Stellate \\
\hline 3. Vesara & Fusion of Nagara \& Dravida \\
\hline
\end{tabular}

The above table shows the classification of Temple Architecture in India with respect to the regional modes of temple architecture. It also gives their respective styles developed gradually with the evolution of each regional mode of Indian temple architecture. Here, however it is necessary to mention the styles of 'Nagara' mode: Latina, Shekhari, Bhumija and Valabhi. Out of these the Latina and Valabhi are contemporaneous; whereas the Shekhari and Bhumija are an outcome of the Latina style of the 'Nagara' mode. A Bhumija Shikhara sits either on an 'orthogonal' plan or a 'stellate' plan of the sanctum of a 'Nagara' temple.

\section{Evolution of the Bhumija Shikhara}

Here we are elaborating on the Nagara temples of India and various sub-styles of this language. But before that it has to be remembered that the development and evolution of different substyles was not a sudden phenomenon but a gradual process. 
The evolution of the Nagara Shikhara from pyramidal, then the curvilinear Ekandaka (single spired)- Latina and finally the fully fledged Anekandaka (multi spired)- Shekhari and Bhumija, can be traced as follows:
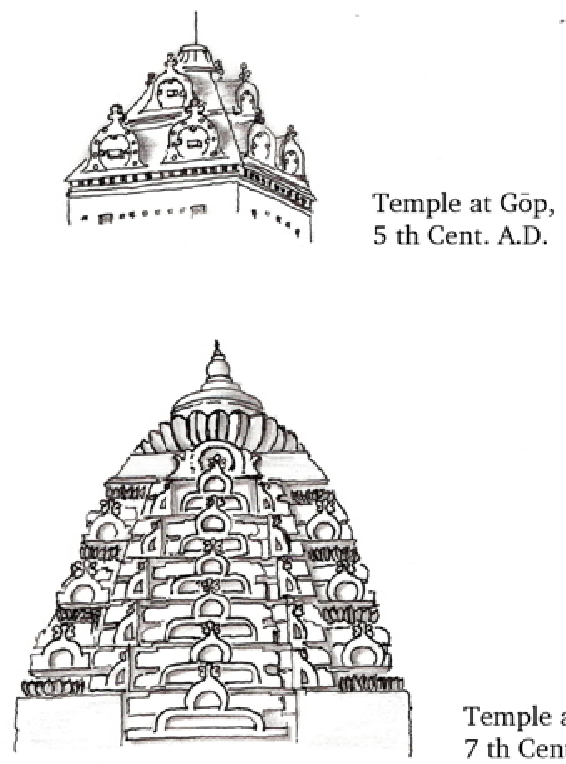

Temple at Sūtrāpāḍa,

7 th Cent. A.D.

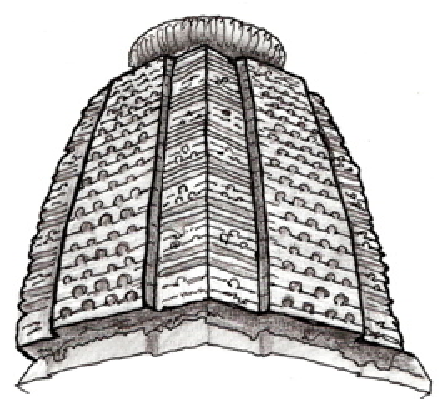

Rōdā. Temple No. 1, c. A.D. 775 ,

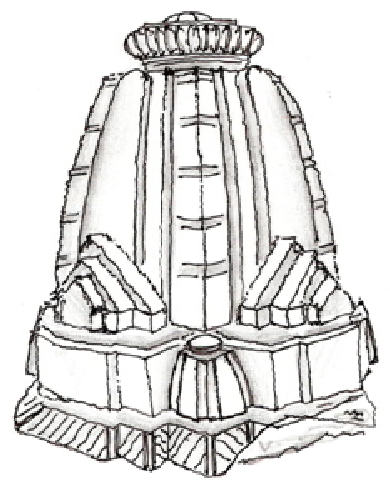

A Pañcāndaka Shrine, Modhera, Early 11 th Cent. A.D.

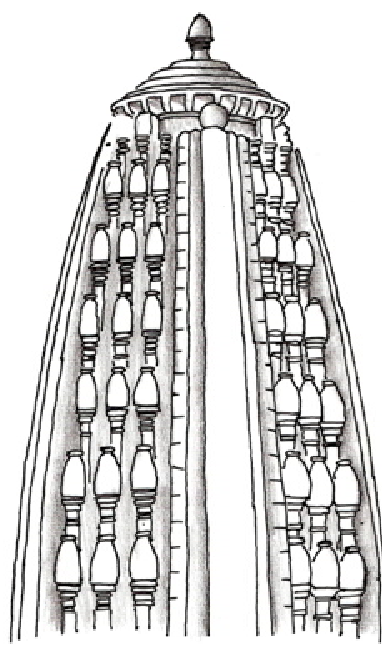

Kirādu. Smaller Śiva Temple No. 1, c. 2 nd quarter of 11 th Cent. A.D.

Mańkeśvara Temple at Jhodga, Mid - 12 th Cent. A.D.

Fig. 1. Evolution of Bhumija Shikhara 
Features of Bhumija Shikhara

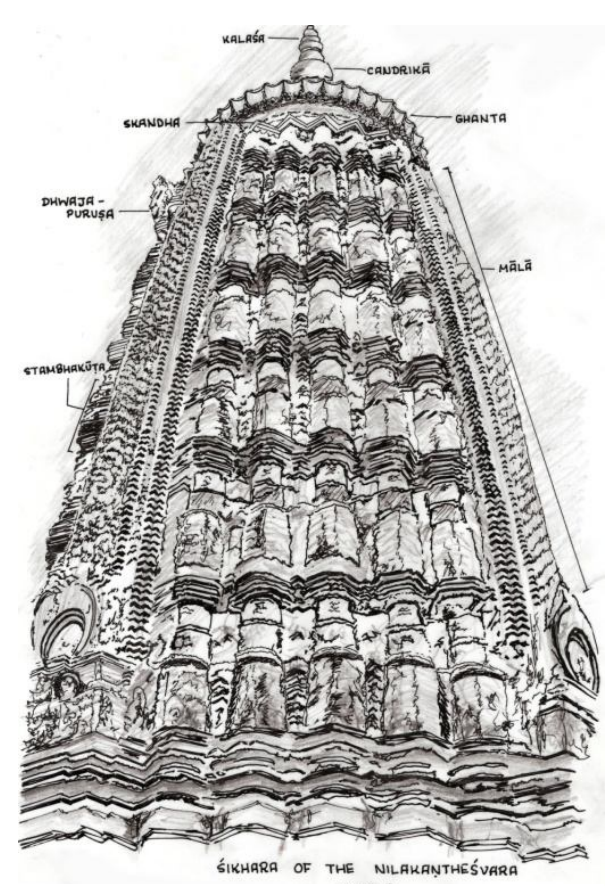

Fig. 2. Features of Bhumija Shikhara

"The Bhumija, one of the two composite styles of Nagara type can be seen as a development of the Latina Shikhara. A Bhumija Shikhara consists of storied arrangement of kutas placed over miniature stambhas arranged in rows, creating an illusion of vertically thrown necklaces of gigantic beads. The Madhyalata receives a strong emphasis in the shape of a mala. The Shurasenaka is made of a single chaitya-dormer. The crowning member is the amalasaraka of a peculiar non Nagara kind where its serration follows the plan of the Shikhara." (Dhaky, 1977)

\section{Meaning of Bhumija}

Etymologically, Bhumija means 'earth born' or 'country born' (Kramrisch, 1976). But the meaning "country-born” loses its validity since, apart from the Samaranganasutradhara, it is also used in the Aparajitapruccha and the Lakshmanasamucchaya compiled outside Malava. The Aparajita gives a lengthy discussion on the origin of the fourteen medieval temple-types and while it attributes the origin of all other temple-types to the deities and demons, Bhumija is the only class attributed to the human kings. Thus Bhumija might mean "of a secular origin" unlike the other forms which were believed to be of a divine or a super-natural origin. Again, since 'bhumi' is an architectural term meaning "storey", this gives a third interpretation of the word Bhumija meaning "born of the storey". This may indicate that, Bhumija was the only Nagara-mode arisen with the living memory of the compilers and that the favour accorded to it by some royal dynast was known.

The Bhumija style has certain marked peculiarities, with Shikhara being the chief one. The Shikhara shows four latas with the usual chaitya arches on the central rathas and a distinctive grouping of miniature Shikharas of diminishing heights on the four quadrants between the latas, the number of these miniature Shikharas varying from three to five rows vertically and five to nine rows horizontally. Decorative in style, they are called kutastambha or stambhakuta in the texts, meaning kuta (miniature Shikharas) resting on pilasters. The sculptured medallion within a large chaitya window (Shurasenaka) at the base of the lata on the three sides and corresponding to the same feature appearing a little higher up as a Shukanasa on the front face of the Shikhara; the Shurasenaka applied on the face of the Shukanasa is as a rule larger and more elaborate. The temples of this mode are essentially 'nirandhara', for a sandhara plan is incompatible with the Bhumija Shikhara. There are other directives also given in the texts - as in the proportions of the doorway, the pitha (socle) and in elevational features - which the extant monuments generally follow. These texts devote a chapter exclusively to a detailed description of the ground plan, elevation and ornamentation of the Bhumija temples of three varieties of plan, namely, caturashra (orthogonal), vritta (circular) and ashtashala (comprising of eight bhadras or principal offsets).

\section{Indian states possessing Bhumija shrines}

In India there are four main northern states possessing fully fledged Bhumija shrines: Madhya Pradesh, Maharashtra, Rajasthan and Gujarat. However it should be noted that Malava (current 
Madhya Pradesh region) is believed to be the homeland of Bhumija style of North Indian Hindu temples.

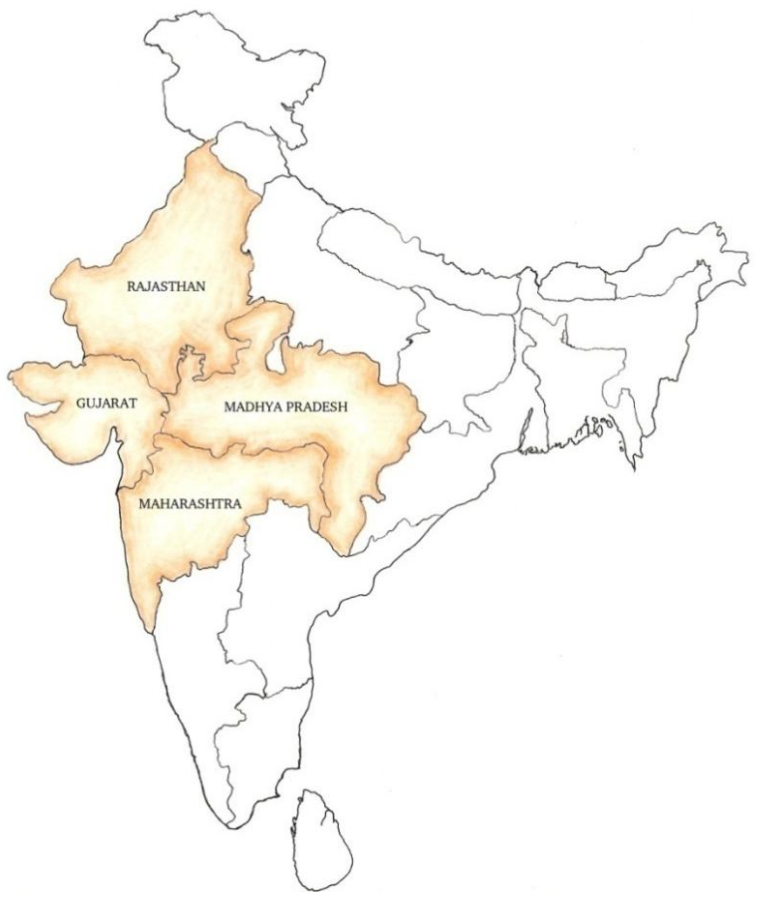

Fig. 3. Indian States possessing fully fledged Bhumija Shrines

On the basis of the research carried out by Prof. Krishna Deva, published in Studies in Indian Temple Architecture, (Deva, 1975) a state-wise list of Bhumija Shrines in India could be furnished. The same are given as follows:

Bhumija temples in M.P:

\begin{tabular}{|c|c|c|c|c|c|}
\hline Sl. & Name of temple & Period & Site & Type of Plan & Elevation \\
\hline 1 & Udayeshvara temple & $1080 \mathrm{AD}$ & Udaypur & $\begin{array}{l}\text { Stellate cum-circular and } \\
\text { saptaratha }\end{array}$ & sapta bhuma \\
\hline 2 & Jamaleshvara temple & $\begin{array}{l}1080-90 \\
\mathrm{AD}\end{array}$ & Jamli, Dhar & $\begin{array}{l}\text { Orthogonal type and } \\
\text { pancharatha }\end{array}$ & panchabhuma \\
\hline 3 & Eight temples at Un & - & $\begin{array}{l}\text { Un, West } \\
\text { Nimar }\end{array}$ & $\begin{array}{l}\text { Stellate. Some are } \\
\text { pancharatha and others are } \\
\text { saptaratha on plan }\end{array}$ & panchabhuma \\
\hline 4 & $\begin{array}{l}\text { Around half dozen } \\
\text { temples at Omkara } \\
\text { Mandhata } \\
\end{array}$ & $\begin{array}{l}\text { Late }{ }_{11^{\text {th }}} \\
\text { cent. AD }\end{array}$ & $\begin{array}{l}\text { River } \\
\text { Narmada, } \\
\text { East Nimar } \\
\end{array}$ & $\begin{array}{l}\text { Stellate, with pancharatha } \\
\text { or saptaratha plan }\end{array}$ & - \\
\hline 5 & $\begin{array}{l}\text { Two shrines -Siddheshvara } \\
\text { Roofless Shaiva temple }\end{array}$ & $\begin{array}{l}\text { Early } 12^{\text {th }} \\
\text { Cent. AD }\end{array}$ & $\begin{array}{l}\text { Nemawar, } \\
\text { Dewas }\end{array}$ & $\begin{array}{l}\text { Both are stellate and } \\
\text { saptaratha on plan }\end{array}$ & $\begin{array}{l}\text { Siddheshvara is } \\
\text { nine storeyed } \\
\text { i.e. } \\
\text { navabhuma }\end{array}$ \\
\hline 6 & Malavai temple & $\begin{array}{l}14^{\text {th }} \text { cent. } \\
\mathrm{AD}\end{array}$ & $\begin{array}{l}\text { Alirajpur, } \\
\text { Jambua }\end{array}$ & Stellate plan & saptabhuma \\
\hline 7 & Barro Khera & $\begin{array}{l}15^{\text {th }} \text { cent. } \\
\mathrm{AD}\end{array}$ & $\begin{array}{l}\text { Neemach, } \\
\text { Mandsaur }\end{array}$ & Stellate plan & - \\
\hline
\end{tabular}


Bhumija temples in Maharashtra:

\begin{tabular}{|l|l|l|l|l|l|}
\hline S1. & Name of temple & Period & Site & Type of Plan & Elevation \\
\hline $\mathbf{1}$ & Ambaranatha temple & $1060 \mathrm{AD}$ & $\begin{array}{l}\text { Ambarnath, } \\
\text { near Kalyan }\end{array}$ & Orthogonal type & $\begin{array}{l}\text { Similar to those } \\
\text { of Udayeshvara }\end{array}$ \\
\hline $\mathbf{2}$ & $\begin{array}{l}\text { Group of temples at } \\
\text { Balsane with one of them } \\
\text { as the triple shrine temple }\end{array}$ & $\mathrm{AD}$ cent. & $\begin{array}{l}\text { Balsane, } \\
\text { Dhulia }\end{array}$ & $\begin{array}{l}\text { Pancharatha and } \\
\text { panchanga }\end{array}$ & panchabhuma \\
\hline 3 & Mankeshvara temple & $\begin{array}{l}\text { Mid } 12^{\text {th }} \\
\text { cent. AD }\end{array}$ & Jhodga, Nasik & $\begin{array}{l}\text { Triple shrine temple } \\
\text { like the one mentioned } \\
\text { above at Balsane }\end{array}$ & saptabhuma \\
\hline 4 & Gondeshvara temple & $\begin{array}{l}\text { 13th cent. } \\
\text { AD }\end{array}$ & Sinnar, Nasik & $\begin{array}{l}\text { It a panchayatan } \\
\text { Shaiva temple. Main } \\
\text { shrine is saptaratha on } \\
\text { plan. The other four } \\
\text { subsidiary shrines are } \\
\text { pancharatha on plan }\end{array}$ & - \\
\hline 5 & Jagadamba temple & $\begin{array}{l}\text { Late 13 } \\
\text { cent. AD }\end{array}$ & $\begin{array}{l}\text { Kokamthan, } \\
\text { Ahmednagar }\end{array}$ & Stellate plan & - \\
\hline 6 & Amriteshvara temple & $\begin{array}{l}15^{\text {th }} \text { cent. } \\
\text { AD }\end{array}$ & $\begin{array}{l}\text { Ratanwadi, } \\
\text { Ahmednagar }\end{array}$ & Late in style & - \\
\hline
\end{tabular}

Bhumija temples in Rajasthan:

\begin{tabular}{|c|c|c|c|c|c|}
\hline Sl. & Name of temple & Period & Site & Type of Plan & Elevation \\
\hline 1 & Mahavira temple & $1010-20 \mathrm{AD}$ & Sewari, Pali & $\begin{array}{l}\text { Orthogonal and } \\
\text { Pancharatha }\end{array}$ & $\begin{array}{l}\text { shadabhuma, a } \\
\text { feature reserved only } \\
\text { for the stellate type in } \\
\text { texts }\end{array}$ \\
\hline 2 & $\begin{array}{l}\text { Mahanaleshvara } \\
\text { temple }\end{array}$ & $\begin{array}{l}\text { Late } 11^{\text {th }} \text { cent. } \\
\text { AD }\end{array}$ & Menal, Chittor & $\begin{array}{l}\text { Orthogonal and } \\
\text { Pancharatha }\end{array}$ & panchabhuma \\
\hline 3 & $\begin{array}{l}\text { Small temple } \\
\text { situated in a tank }\end{array}$ & $\begin{array}{l}\text { Late } 1^{\text {th }} \text { cent. } \\
\text { AD }\end{array}$ & Near Menal & $\begin{array}{l}\text { Orthogonal and } \\
\text { Pancharatha }\end{array}$ & panchabhuma \\
\hline 4 & Bhand Deora & $\begin{array}{l}\text { Early } \\
\text { cent. AD }\end{array}{ }^{\text {th }}$ & Ramgarh, Kota & Stellate saptaratha & saptabhuma \\
\hline 5 & $\begin{array}{l}\text { Devi temple, } \\
\text { subsidiary shrine at } \\
\text { Shiva temple at } \\
\text { Ramgarh }\end{array}$ & $\begin{array}{l}\text { Early } \\
\text { cent. AD }\end{array}$ & Ramgarh, Kota & $\begin{array}{l}\text { Orthogonal } \\
\text { saptaratha }\end{array}$ & saptabhuma \\
\hline 6 & Undeshvara temple & - & $\begin{array}{l}\text { Bijolia, } \\
\text { Bhilwara }\end{array}$ & $\begin{array}{l}\text { Stellate and } \\
\text { saptaratha on plan }\end{array}$ & navabhuma \\
\hline 7 & Surya temple & $\begin{array}{l}\text { Late } 11^{\text {th }} \text { cent. } \\
\text { AD }\end{array}$ & $\begin{array}{l}\text { Jhalrapatan, } \\
\text { Jhalawar }\end{array}$ & $\begin{array}{l}\text { Orthogonal } \\
\text { saptaratha }\end{array}$ & saptabhuma \\
\hline 8 & Surya temple & $15^{\text {th }}$ cent. AD & Ranakpur & $\begin{array}{l}\text { ashtashala } \\
\text { sanctum and } \\
\text { ashtabhadra } \\
\text { mandapa }\end{array}$ & navabhuma \\
\hline 9 & Adbhutnatha temple & $\begin{array}{l}\text { A generation } \\
\text { later than the } \\
\text { above }\end{array}$ & Chittor & $\begin{array}{l}\text { Pancharatha on } \\
\text { plan }\end{array}$ & - \\
\hline
\end{tabular}


Bhumija temples in Gujarat:

\begin{tabular}{|l|l|l|l|l|l|}
\hline S1. & Name of temple & Period & Site & Type of Plan & Elevation \\
\hline $\mathbf{1}$ & $\begin{array}{l}\text { Ranamukteshvara } \\
\text { temple }\end{array}$ & $\begin{array}{l}10^{\text {th }} \text { AD cent. } \\
\text { AD }\end{array}$ & Makani, Vadodara & $\begin{array}{l}\text { Orthogonal and } \\
\text { Pancharatha }\end{array}$ & $\begin{array}{l}\text { Shadabhuma, a } \\
\text { feature reserved only } \\
\text { for the stellate type in } \\
\text { texts }\end{array}$ \\
\hline $\mathbf{2}$ & $\begin{array}{l}\text { Triple shrine Shiva } \\
\text { temple }\end{array}$ & $\begin{array}{l}1^{\text {th }} \\
\text { AD cent. }\end{array}$ & $\begin{array}{l}\text { Limkheda, } \\
\text { Panchmahal }\end{array}$ & Stellate on plan & - \\
\hline 3 & $\begin{array}{l}\text { Galateshvara } \\
\text { temple }\end{array}$ & $\begin{array}{l}\text { Late 11 } \\
\text { cent. AD }\end{array}$ & Sarnal, Kheda & $\begin{array}{l}\text { ashtabhadra stellate } \\
\text { plan }\end{array}$ & saptabhuma \\
\hline
\end{tabular}

\section{Spatial distribution of Bhumija shrines in India}

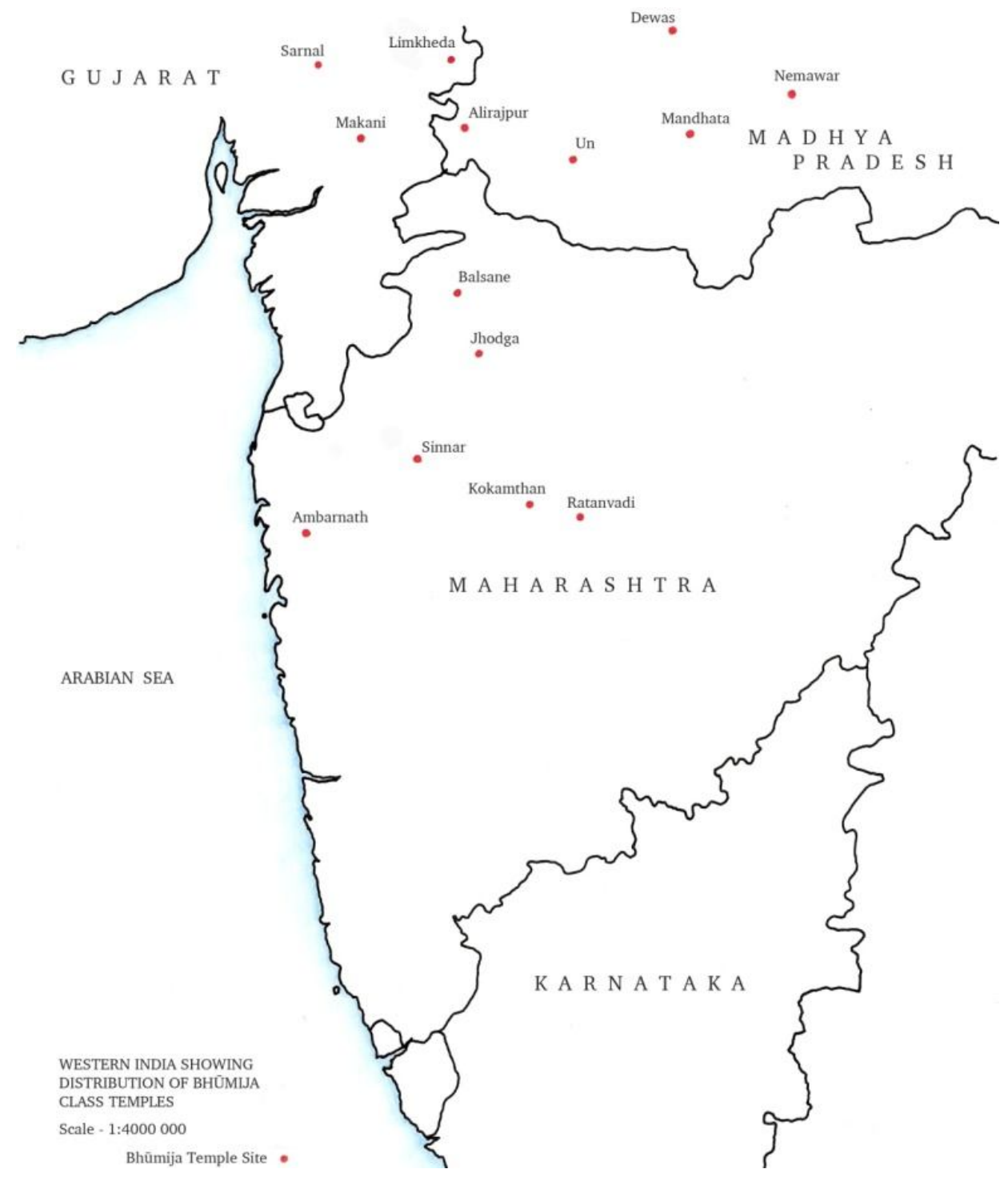




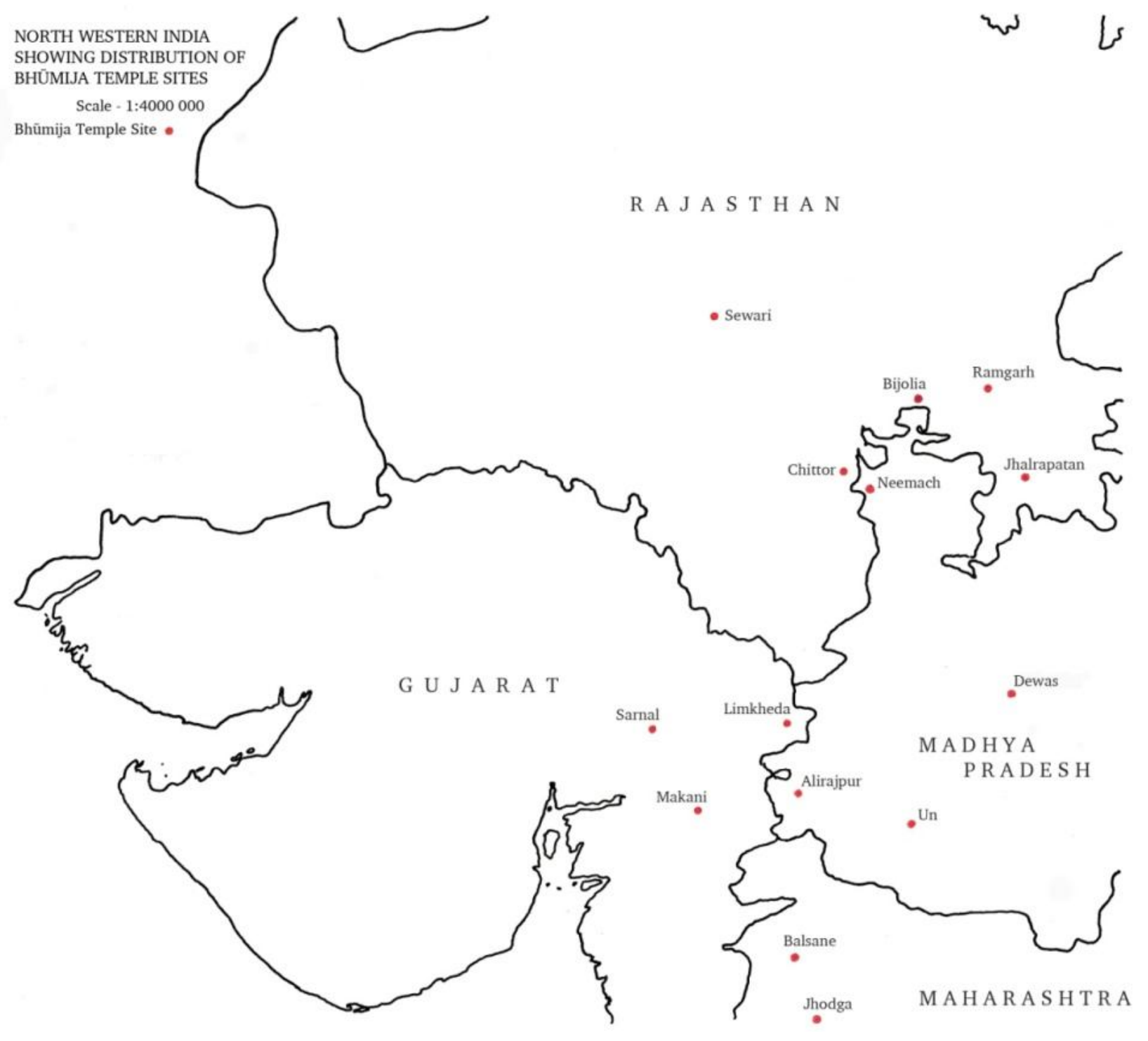

\section{Findings}

As mentioned earlier in the paper Malava (M.P) is believed to be the land of origin of Bhumija style. But still as evident from the above tables, the earliest Bhumija temple known so far is not in M.P. It is in Gujarat - the Ranamukteshvara temple. This implies two possibilities:

1. That the style might have originated near to this region of Gujarat, or

2. That this region of Gujarat might have been a part of the then Malava.

In any case, nothing can be said firmly at this point of time. This assertion can be achieved only after further research in the direction. as follows:

The graph showing the time-line of various Bhumija shrines across states of India is shown 


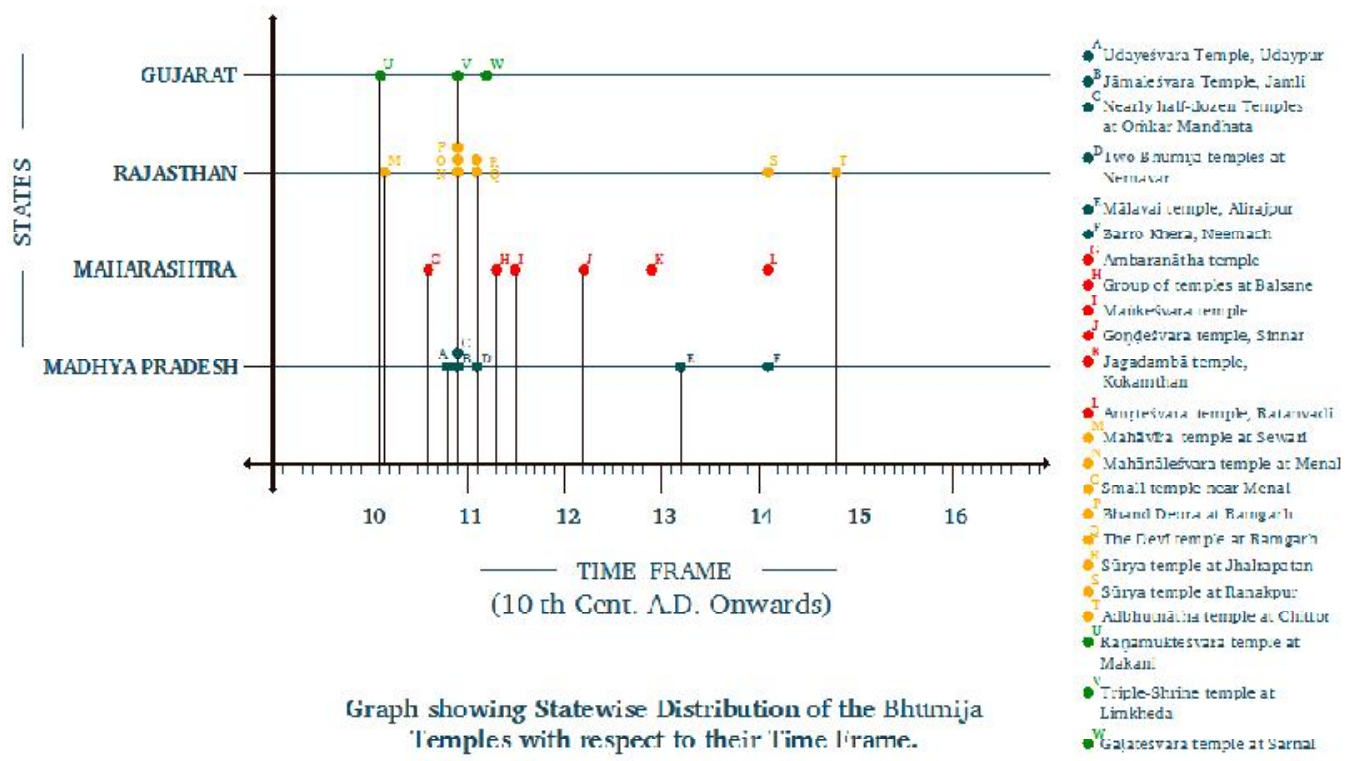

\section{Endnote:}

i. All sketches and drawings are reproduced from the unpublished B. Arch. Thesis of the author submitted to S.V.I.T, Vasad in the year 2006.

\section{References}

Albanese, M. Architecture in India, New Delhi, India, 2004, p. 18

Dhaky, M. A. The Indian Temple Forms in Karnata inscriptions and Architecture, Abhinav Publications, New Delhi, India, 1997, p.19

Hardy, A. Indian Temple Architecture - Form and Transformation (First ed.), (Ed.) Adam Hardy, Indira Gandhi National Centre for the Arts, Abhinav Publications, New Delhi, India, 1995, p.7

Kramrisch, S. The Hindu Temple" (Vol. 1), Motilal Banarasidas, Calcutta, India, 1976, p. 389.

Krishna Deva. Bhumija Temples, "Studies in Indian Temple Architecture", (Ed.) Pramod Chandra, American Institute of Indian Studies, Varanasi, India, 1975.

The Authors are Architects, Urban Planners and Educators. They are working as core faculty members with Faculty of Architecture, Parul University, Waghodia, Vadodara, Gujarat, India E Mail IDs: hajarnismaulik@gmail.com, bhagyajit.raval@gmail.com 